\title{
Değerler Eğitiminde Örnek Bir Kurum: Bayrampaşa Bilgi Merkezi
}

\author{
Muhammet Ü. Öztabak ${ }^{1}$
}

\section{$\ddot{O} z$}

Değerler, önemli yaşam hedefleri ya da bireyin yaşamına yol gösteren standartlar olarak tanımlanabilir. Değerler, davranışlara kaynaklık eden ve onları yargılamaya yarayan anlayışlardır. Değerler ayrıca, bireylerin neyi önemli gördüklerini tanımlayarak istekleri, tercihleri, arzu edilen ve edilmeyen durumları gösterir. Eğitimin bir işlevi de toplumsal değerlerin gelecek kuşaklara aktarılmasıdır. Ebeveynler, çocuklarının okullarda aldıkları değerler eğitimini yetersiz görüp takviye amaçlı farklı kurumları devreye sokmuşlardır. Böylece çocuklarının, aile ve okul dışında geçirecekleri zamanı ve çevreyi mümkün olduğunca güvenilir kurumlarda geçirmelerini sağlamış olmaktadırlar. $\mathrm{Bu}$ araştırmanın amacı, öğrencilere sosyal, sportif, kültürel, ahlaki, sanatsal ve akademik yönlerden katkı sağlamak amacıyla kurulmuş bir yaygın eğitim kurumu olan İstanbul Bayrampaşa Bilgi Merkezinde 4 ila 8. sınıf öğrencilerine yönelik yürütülen değerler eğitimi modelinin incelenmesidir. Araştırmada, nitel araştırma yöntemlerinden "Durum Çalışması" deseni kullanılmıştır. Araştırmadaki veriler; ilgili literatür taramasıyla, öğretmenlerle yüz yüze yapılandırılmış görüşme yöntemi kullanılarak ve kurumda uzun süreli gözlemler yapılarak elde edilmeye çalışılmıştır.

\section{Anahtar Kelimeler}

Değerler eğitimi, Bilgi merkezi, Bilgi evleri, Yaygın eğitim, İlköğretim

1 Yetkilendirilmiş yazar: Muhammet Ü. Öztabak, Fatih Sultan Mehmet Vakıf Üniversitesi Eğitim Fakültesi Eğitim Bilimleri Bölümü, Rehberlik ve Psikolojik Danışmanlık Anabilim Dalı, Üsküdar İstanbul, E-posta: muoztabak@fsm.edu.tr, ORCID ID: 0000-0003-4923-2163 


\title{
An Examplary Institution in Values Education: Bayrampasa Knowledge Center
}

\author{
Muhammet Ü. Öztabak
}

\begin{abstract}
Values can be defined as important life goals or standards that guide the individual's life. Values are understandings that are the source of behaviours and serve to judge them. Values also indicate what the individuals see as important, their desires, their preferences, and desired and undesirable situations. A function of education is to transfer social values to future generations. Parents consider the values education of their children's receiving in schools as insufficient and put in place different institutions for reinforcement. They ensure that their children spend time outside their family and school, and spend their time in a safe environment wherever possible. The aim of this research is to examine the model of values education conducted for 4th to 8 th grade students at Istanbul Bayrampasa Knowledge Center, a non-formal education institution established to contribute social, sportive, cultural, ethical, artistic and academic aspects to the students. In the research, "Case Study" was used in qualitative research methods. The data in the study obtained by the screening of relevant literature, face-to-face structured interviews with teachers, and long-term observations at the institution.
\end{abstract}

\section{Keywords}

Values education, Knowledge center, Knowledge homes, Continuous education, Primary education

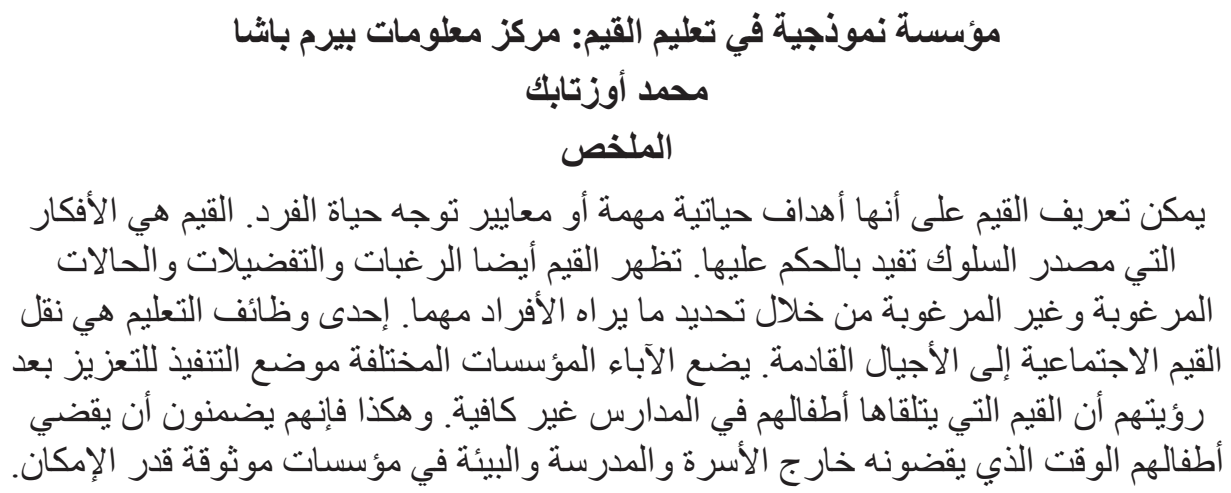




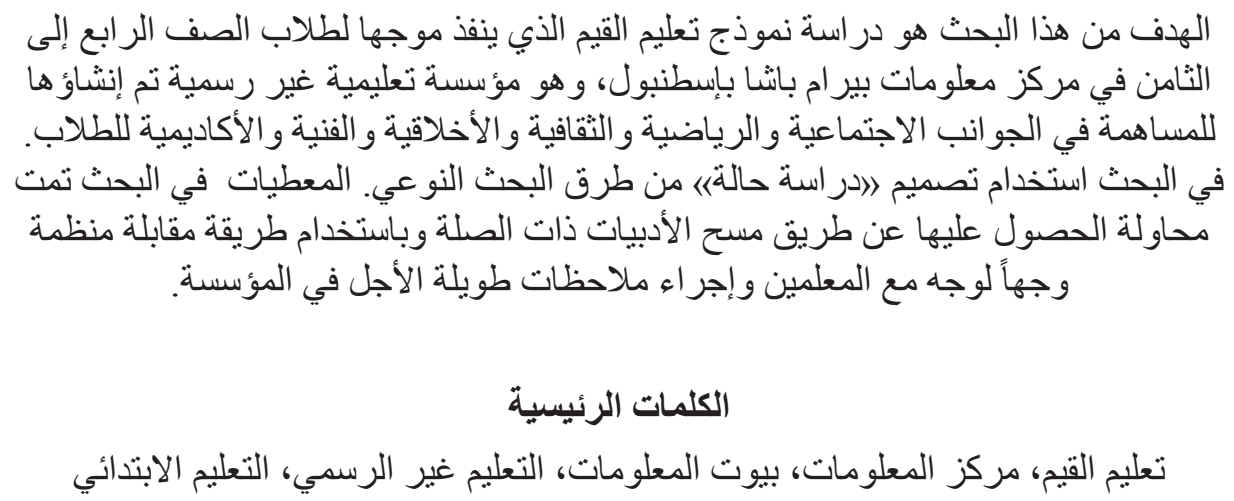

\section{Giriş}

Bilginin hızla geliştiği, çoğaldığı ve yayıldığı dünyamızda eğitim paradigmaları da değişmiş, buna paralel, okulların ve öğretmenlerin işlevlerinde de değişiklikler meydana gelmiş, salt bilgi aktarıcı konumlarından uzaklaşılmıştır. Günümüzde oluşan bilgi havuzunda yüzme öğreten tek kurum okul olmaktan çıkmış durumdadır. Zaten okullar da eskisi gibi bu misyonu üstlenen tek kurum olma iddiasını sıkı sıkıya savunmamaktadırlar. Öğrenmenin belli bir yaşla, kurumla, mekânla, kişiyle, araçla sınırlı kalamayacağı gerçeğinden hareketle insanın doğumundan ölümüne kadar, her mekânda, birçok farklı kurumda veya ortamda, farklı kişilerle, farklı araç-gereç ve metotlarla öğrenebileceği üzerinde durulmaktadır. Buna atfen "Hayat Boyu Öğrenme" kavramı ortaya çıkmıştır.

Belirli bir plan ve program etrafında şekillenerek okul ya da kurumlarda gerçekleştirilen eğitime formal/biçimsel eğitim adı verilir (Demirel ve Kaya, 2009). Formal eğitim, örgün ve yaygın eğitim olmak üzere iki alanda çeşitlenmiştir. Örgün eğitim, belirli yaş grubundaki ve aynı seviyedeki bireylere, amaca göre hazırlanmış programlarla okul çatısı altında verilen düzenli eğitimdir. Örgün eğitim imkânlarından faydalanamayan, gittikleri okullarda erken ayrilma durumunda bulunan ya da örgün eğitim kurumlarında öğrenim gören ve mesleki anlamda daha yeterli duruma gelmek isteyen bireylere verilen eğitime yaygın eğitim denilmektedir (Yücel, 2014, s. 19). Yaygın eğitim kurumları günümüzde gitgide çoğalmaktadır. İnsanların sürekli kendilerini geliştirme ve yenileme, yeni meslekleri takip etme, okulların eksiklerini kapama, boş zamanlarını değerlendirme, yeni hobiler edinme, değişen gündemi ve piyasaları takip etme istekleri yaygın eğitim kurumlarına olan talebi ve gereksinimi artırmaktadır. Kılıç’a (1983) göre yaygın eğitim; çevrede, iş yerinde, ailede, her yerde ve her firsatta vatandaşlara sürekli verilen yaşam boyu eğitimi kapsamaktadır.

Değerler için pek çok farklı tanım yapılmıştır. Değerler "bireyin ya da bir toplumsal oluşumun yaşamına yol gösteren ilkelere" hizmet eden, tercih edilen davranış ve oluş biçimleri hakkındaki öğrenilmiş inançlar olarak tanımlanmıştır (Schwartz, 1994; Costa ve McCrae, 2001). Rokeach’e (1973) göre değerler, “önemli yaşam hedefleri 
ya da bireyin yaşamına yol gösteren standartlar" olarak tanımlanabilir. Çağlar (2005) değerleri, bireylerin düşünce, tutum ve eylemlerinde birer standart olarak ortaya çıkan kültürel ögeler olarak ifade etmiştir. Soykan'a (2007, s. 48) göre değerler "yapılıp edileni önemli, anlamlı kılan şeydir." Köknel (2007, s. 17) ise değerleri; "somut ya da soyut kavramların önemini belirtmeye yarayan soyut ölçü birimi, canlı ve cansız varlıkların, olayların, olguların durumunu önemini anlatan bir sözcük" olarak tanımlamaktadır. Güngör (2000, s. 27-28) de değerleri: "belirli bir davranışın ya da herhangi bir şeyin tercih edilebilir veya edilemez olduğu hakkındaki kalıı inanç" olarak tanımlamıştır.

Değerler manevi ve manevi olmayan diye ikiye ayrılır. Manevi (ahlaki) değerler; dürüstlük, sorumluluk ve iyilik gibi zorunluluk taşır. Sözümüzü tutmak, faturalarımızı ödemek, çocuklarımıza bakmak ve başkalarıyla olan ilişkilerimizde dürüst olmak zorunluluğu gibi. İstemesek de bu tür değerlere riayet etmek zorundayızdır. Manevi olmayan değerler zorunluluk ya da yükümlülük taşımazlar. Bu değerler ne yapmak istediğimizi ya da ne yapmak istemediğimizi anlatırlar. Örneğin; bireyin kişisel değeri klasik müzik dinlemek ya da iyi bir roman okumak olduğu farz edilirse, bireyin bunları yapma zorunluluğu yoktur (Thapor, 2001).

Değerlerden sonra okulun tanımına ve işlevine kısaca yer vermek yerinde olacaktır. Ögülmüş ve Çok'a (1996) göre; okul kendine özgü yapısı, amaçları ve işlevleri olan bir örgüttür (Akt. Çalık, 2008, s. 7). Eğitim bir kamu hizmetidir ve eğitim resmi anlamda bireylerin değerler, yetenekler ve bilgi bakımından eğitildiği toplumsal kurumlar olan okullarda verilmektedir (Aydın, 2006). Aynı zamanda okullar, ailede kazanılan değerlerin daha da pekiştirileceği ve bazı yeni değerlerin kazanılacağı ortamlardır. Ailede olduğu gibi okulda da değerler eğitiminin yaşantıların bir parçası hâline getirilerek verilmesi en uygun olan yoldur (Hökelekli ve Gündüz, 2007, s. 389).

Okulun varoluşsal nedeni; planlı etkinlikler aracıllğı ile öğrencilerde istendik yönde bilişsel, duyuşsal ve psikomotor davranışlar kazandırmaktır. Fakat okulun bu işlevlerini yerine getirip getiremediği tartışmalı bir konudur (Özdemir ve Kalaycı, 2013). Aynı şekilde değerler eğitimi noktasında da okulun ne kadar tatmin edici bir işlevinin olduğu sorgulanabilir. $\mathrm{Bu}$ sebeple insanlar örgün eğitimin yanında alternatif yaygın eğitim kurumları açmayı uygun görmüşlerdir. Ebeveynler, çocuklarının okullarda aldıkları değerler eğitimini yetersiz görüp takviye amaçlı farklı kurumları devreye sokmuşlardır. Böylece çocuklarının, aile ve okul dışında geçirecekleri zamanı ve çevreyi mümkün olduğunca güvenilir ortamlarda geçirmelerini sağlamış olmaktadırlar.

Bu kurumlardan birisi de Bayrampaşa ilçesinde bulunan Bilgi Merkezidir. Ev ve okuldan sonra "Öğrencinin Üçüncü Adresi” sloganıyla yola çıkan Bayrampaşa Bilgi Merkezi, Bayrampaşa Belediyesi tarafından Mayıs 2005 yılında kurulmuştur. Bilgi Merkezi; etüt salonları, bilgisayar laboratuvarı, kütüphane, kapalı spor salonu, açık basketbol ve futbol sahası, konferans salonu, rehberlik servisi ve idari bölümüyle 9-15 yaşları arasındaki çocuklara ücretsiz olarak hizmet veren bir kurumdur. Öğrenciler, kontenjanların sınırlı olması ve diğer öğrencilerin de bu hizmetlerden yararlanabilmesi için en fazla üç yıl bu hizmeti alabilmektedirler. Öğrencilerin, okul saatleri dışında 
öğretmenlerin gözetiminde ders çalışabilecekleri ve ödevlerini yapabilecekleri, sanatsal, kültürel ve sportif faaliyetlere katılarak zamanlarını değerlendirebilecekleri güvenli bir ortam sunulmaktadır.

Bayrampaşa Bilgi Merkezi, örgün eğitime destek veren bir nitelikte hizmet vermektedir. Öğrenci her gün iki saat etüt hizmeti almakta ve ayrıca en fazla üç kulübe katılabilmekte, dolayısıyla yaklaşık 15-20 saatini kurumda geçirmektedir. Öğrencilerin sokaktan kurtarılarak denetimli bir şekilde eğitim-öğretime dahil edilmesi hem öğrenciler hem de aileler adına büyük bir avantaj oluşturmaktadır.

Bilgi Merkezi, çocuğun ruhen, bedenen ve zihnen gelişmesini önemsemekte, bunun için aşağıdaki eğitim ilkelerini uygulamaktadır;

a. Çoklu zekâ kuramı gereği öğrencilerin farklı özellikleri geliştirilmeye çalışılmaktadır.

b. Değerler eğitimi yapılmaktadır. Bunun için 30 civarında değer/kavram öğrencilere aktarılmaya çalışılmaktadır.

c. Eğitimde aile çok önemsenmekte ve aile eğitimin bir parçası hâline getirilmeye çalışılmaktadır.

d. Etüt eğitim merkezi ve halk evleri yapılarının karışımı bir yapı denenmektedir.

e. Ortak çalışma yapmak isteyen Sivil Toplum Kurumları ile ortak çalışmalar yapılmaktadır (ör: Kızılay, Yeşilay).

f. Eğitimde olabildiğince farklı ve yeni unsurlar kullanılmaya çalışılmaktadır. (Ör: Facebook/ twitter, geleneksel çocuk oyunlarının gündemde tutulması, izcilik, aile bültenleri, eğitim portalı, çocuk dergileri: Hayal Treni, Yıldızlı Nehir).

g. Eğitimin her safhasında bütüncül bir bakış açısı getirmeye çalışılmaktadır. Bütüncül bakış açısı çok farklı araçlarla kuvvetlendirilmeye ve eğitim ağına giren çocuk ve aile olabildiğince kuşatılmaya çalışılmaktadır (Ör: Aylık olarak aile ve çocuk seminerleri, el ve hayat becerisi çalışmaları, birebir aile görüşmeleri, sosyal, kültürel, sportif, sanatsal kulüpler, yarışmalar, paneller, münazaralar).

\section{Araştırmanın Amacı}

$\mathrm{Bu}$ araştırmada, öğrencilere sosyal, sportif, kültürel, ahlaki, sanatsal ve akademik yönlerden katkı sağlamak amacıyla kurulmuş bir yaygın eğitim kurumu olan İstanbul Bayrampaşa Bilgi Merkezinde 4 ila 8. sınıf öğrencilerine yönelik yürütülen değerler eğitimi modelinin incelenmesi amaçlanmıştır. $\mathrm{Bu}$ amaca uygun olarak aşağıdaki sorulara cevap aranmaya çalışılmıştır:

1. Bilgi Merkezinde değerler eğitimiyle ilgili ne tür uygulamalar yapılmaktadır? 
2. Bilgi Merkezinin değerler eğitiminde diğer kurumlardan farkl1llğı nelerdir?

3. Bilgi Merkezinde uygulanan değerler eğitimine ilişkin geri bildirimler nasıl alınmaktadır?

4. Bilgi Merkezinde değerler eğitiminde yaşanılan zorluklar nelerdir?

\section{Yöntem}

\section{Araştırma Modeli}

Araştırmada, nitel araştırma yöntemlerinden "Durum Çalışması" deseni kullanılmıştır. Durum çalışması, bir sınıf, bir mahalle, bir örgüt gibi doğal bir çevre içinde gerçekleştirilir ve çalışmaya konu olan ortam veya olayların bütüncül bir yorumunu hedefler (Yıldırım ve Şimşek, 2013). Bu araştırmada Bayrampaşa Bilgi Merkezinde uygulanan "değerler eğitimi" incelenmeye çalışılmıştır.

\section{Çalışma Grubu}

Araştırma, İstanbul Bayrampaşa ilçesinde bulunan "Bayrampaşa Bilgi Merkezi" adlı etüt merkezinde yapılmışıtır. Bilgi Merkezinde 4 ila 8. sınıf öğrencilerine yönelik okul dışı zamanlarda çeşitli kulüp ve etüt çalışmaları yapılmaktadır. Bilgi Merkezinde 500 'den fazla öğrenci eğitim almakta ve tam/yarı zamanlı 21 öğretmen çalışmaktadır.

Araştırmanın çalışma grubu, 2'si erkek, 8'i kadın toplam 10 öğretmenden oluşmaktadır. Araştırmada, amaçlı örnekleme yöntemlerinden kolay ulaşılabilir durum örneklemesi yöntemi kullanılmıştır. Kolay ulaşılabilir durum örneklemesi, araştırmaya hız ve pratiklik kazandırır. Çünkü bu yöntemde araştırmacı, kendisine yakın olan ve erişilmesi kolay olan bir durumu seçer (Yıldırım ve Şimşek, 2013).

\section{Verilerin Toplanması}

Görüşmeler, Bilgi Merkezi yönetiminin izni ile yapılmıştır. Öğretmenlerin araştırmaya katılımı, gönüllülük esasına göre gerçekleştirilmiştir. Uygulama sürecinde öğretmenlere görüşmenin amacı kısaca anlatılmış, öğretmenlere ait özel bilgilerin ve görüşmelerin gizli kalacağı, soruları cevaplarken gerçek düşüncelerini söylemekten çekinmemeleri gerektiği belirtilmiştir. Öğretmenlerle görüşme öncesi sıcak bir ortam oluşturulmuş, çay-kahve içilerek her bir öğretmenle kısa bir tanışma yapılmış, konuşmaları yönünde cesaretlendirilmiş ve teşvik edilmiş fakat tarafsız olma adına hiçbir yönlendirme yapılmamıştır. Öğretmenlerle yüz yüze görüşmeler yöneticilerin müsait olan odalarında gerçekleştirilmiştir. Öğretmenlerin verdikleri cevaplar yine onların izinleri alınarak ses kayıt cihazıyla, izin vermeyen öğretmenlerin cevapları ise not edilerek kayıt altına alınmıştır. 
Araştırmaya katılan öğretmenlerin demografik özellikleri Tablo 1'de sunulmuştur.

Tablo 1.

Ögretmenlerin Demografik Özellikleri

\begin{tabular}{|c|c|c|c|c|c|c|}
\hline Öğretmen & Görev & Branş & Yaş & Cinsiyet & $\begin{array}{l}\text { Kaç yıldır } \\
\text { bu kurumda } \\
\text { çalışmakta? }\end{array}$ & $\begin{array}{l}\text { Meslekte } \\
\text { kaçıncı } \\
\text { yılı? }\end{array}$ \\
\hline Öğrt. 1 & Rehberlik & Okul Öncesi Öğr. & 42 & $\mathrm{~K}$ & 6 & 20 \\
\hline Öğrt. 2 & $\begin{array}{l}\text { Etüt, Mat., } \\
\text { Gezi }\end{array}$ & Tekstil Öğr. & 27 & $\mathrm{~K}$ & 4 & 4 \\
\hline Öğrt. 3 & Ed., Dergi & Bilgi Belge Yön. & 39 & $\mathrm{~K}$ & 9 & 12 \\
\hline Öğrt. 4 & Etüt, Sos. Bil. & Tarih & 38 & $\mathrm{~K}$ & 9 & 11 \\
\hline Öğrt. 5 & Müdür Yrd. & Fizik & 38 & $\mathrm{~K}$ & 9 & 14 \\
\hline Öğrt. 6 & Etüt, Fen Bil. & Biyoloji & 29 & K & 1 & 5 \\
\hline Öğrt. 7 & Müdür Yrd. & Kimya & 33 & $\mathrm{E}$ & 9 & 10 \\
\hline Öğrt. 8 & Bilgisayar & Bilgisayar & 30 & $\mathrm{E}$ & 4 & 8 \\
\hline Öğrt. 9 & Etüt, Sos. Bil. & Edebiyat & 28 & $\mathrm{~K}$ & 5 & 5 \\
\hline Öğrt. 10 & Rehberlik & Psikoloji & 27 & $\mathrm{~K}$ & 4 & 5 \\
\hline
\end{tabular}

Araştırmaya katılan öğretmenlerin 8'i kadın, 2'si erkektir. Öğretmenlerin yaş ortalamaları 33,1 senedir. Kurumda çalışma yılı ortalaması 6 senedir. Öğretmenlerin meslekte geçirdikleri yıl ortalaması ise 9,4 yıldır.

\section{Veri Toplama Araçları}

Araştırmanın verileri, yüz yüze yapılandırılmış görüşme yöntemi ile toplanmıştır. Araştırmada öğretmenlere araştırmacı tarafından hazırlanan beş adet açık uçlu soru sorulmuştur. Bu sorular aşağıda belirtilmiştir.

1. Değerler eğitimi ile ilgili ne tür uygulamalarınız var?

2. Kurum olarak değerler eğitimi ile ilgili hangi açılardan kendinizi farklı görüyorsunuz?

3. Verdiğiniz değerler eğitiminin geri bildirimini nasıl alıyorsunuz?

4. Değerler eğitimi ile ilgili yaşadığınız zorluklar nelerdir?

5. Değerler eğitimi ile ilgili öğretmenlere ve kurumlara tavsiyeleriniz nelerdir? 
Ayrıca demografik bilgileri öğrenmek amacıyla öğretmenlere; görev, branş, yaş, cinsiyet, kurumda çalışma süresi, meslekteki çalışma süresi soruları yöneltilmiştir.

\section{Verilerin Analizi}

Veri analizinde Miles ve Huberman'ın (1994) üç aşamalı süreci takip edilmiştir (akt. Yıldırım ve Şimşek, 2013, s. 255). Bunlar;

a. Verilerin işlenmesi,

b. Verinin görsel hale getirilmesi,

c. c. Sonuç çıkarma ve teyit etme.

"Verilerin işlenmesi aşamasında araştırmacı, önce veriyi inceler ve kodlar. Veriyi kodlarken araştırma problemine göre önemli olan kavramları ve temaları kullanır. $\mathrm{Bu}$ şekilde veri özetlenmiş ve önemli olanları seçilmiş olur. Daha sade ve araştırma problemiyle uyumlu hale gelen veri seti, ikinci aşamada çeşitli grafikler, tablolar ve şekiller yoluyla görsel hale getirilir. Son aşamada ise, ortaya çıkan kavramlar, temalar ve ilişkiler yorumlanır, karşılaştırılır ve teyit ediliı" (Miles ve Huberman, 1994; akt. Yıldırım ve Şimşek, 2013, s. 255).

\section{Geçerlik ve Güvenirlik}

Nitel araştırmada "geçerlik" bilimsel bulguların doğruluğu, "güvenirlik" ise bilimsel bulguların tekrarlanabilirliği ile ilgilidir. Araştırmada geçerlik ve güvenirliği sağlamak amacıyla inandırıcılık, aktarılabilirlik, tutarlılık ve teyit edilebilirlik (Yıldırım ve Şimşek, 2013) gibi stratejilerden yararlanılmıştır. Araştırmanın geçerliği ve güvenirliğini artırmak amacıyla şu önlemler alınmıştır;

Araştırmanın iç geçerliğini (inandırıcılığını) artırmak için alan yazın taraması yapılmış, konuyla ilgili kavramsal bir çerçeve çizilerek görüşme soruları geliştirilmiştir. Yapılan veri analizinde temalar, ilgili kavramları içine alacak ve ilgisiz kavramları dışarıda bırakacak şekilde belirlenmeye ve temalar arası ilişkiler kontrol edilerek bir bütünlük oluşturulma çalışılmıştır. Görüşmeler kurum yönetiminin izniyle ve gönüllü öğretmenlerle gerçekleştirilmiş, samimi bir ortamda karşılıklı güvenin oluşmasına gayret edilmiş, böylece verilen cevapların samimi ve gerçek verileri yansıtmasına çalışı1mıştır. Araştırmanın dış geçerliğini (aktarılabilir olmasını) artırmak için araştırma sürecinde tüm yapılanlar ayrıntılı bir şekilde açıklanmaya çalışılmıştır. Ayrıca, araştırmanın modeli, araştırmanın yapıldığ 1 yer ve durum, çalışma grubu, verilerin toplanması, veri toplama araçları, verilerin analizi ve yorumlanması ayrıntılı bir biçimde tanımlanmıştır.

Araştırmanın iç güvenirliğini (tutarlığını) artırmak için elde edilen bulgular yorum yapılmadan aktarılmıştır. Ayrıca elde edilen veriler, bir uzmanla karşılıklı değerlendirilerek verilerin tutarlılığı karşılaştırılmıştır. Araştırmanın dış güvenirliğini (teyit edilebilirliğini) artırmak için süreçte yapılanlar araştırmacı tarafından ayrıntılı bir biçimde tanımlamıştır. Ayrıca elde edilen ham veriler ve kodlamalar araştırmacı tarafindan saklanmaktadir. 


\section{Bulgular}

Öğretmenlerle birebir görüşmelerden elde edilen bulgulara geçmeden önce Bilgi Merkezinin değerler eğitimi bazında işleyişi hakkında bilgi verilecektir.

\section{Bilgi Merkezinde Değerler Eğitimi}

Bilgi Merkezini diğer benzeri kurumlardan ayıran en önemli yönü değer aktarımı için kullanılan 30 civarında (bunlara ihtiyaca göre yenileri eklenebilir) kavramın müfredata yedirilerek çocuklara aktarılmaya çalışılmasıdır. Bu kavramlar tüm faaliyetlerin merkezi hâline getirilmeye çalışılmakta, örgün eğitimle sağlıklı bir ilişki kurabilmek için Belirli Gün ve Haftalar listesini değerlerle/kavramlarla buluşturup işlemeye çalışılmaktadır. Örneğin;

Ocak - Dünya Çocuk Kitapları Haftası: okuma - tefekkürün önemi,

Mart - İstiklal Marşı'nın Kabulü: bağımsızlık ve istiklal,

Ekim - Ahilik Haftası: iş ahlakı - dayanışma - cömertlik,

Aralık - Vakıf Haftası: hizmet - sorumluluk - paylaşma.

Bu çalışmanın daha önce bir örneği olmadığı için müfredat oluşturulmakta, değişen şartlara göre temel noktaları değiştirmeden geliştirme yolları aranmaktadır. Çalışmanın müfredatında kademe anlayışı vardır, yani birkaç sene devam eden çocukların programları farklılaşmaktadır.

Kavramlar bütün kulüplerde aynı zamanda, kulüplerin içeriklerine göre farklı şekillerde ele alınmaktadır. Bilgi Merkezindeki kulüp yelpazesinin gayet geniş olduğu görülmektedir. Öğrencilerin ilgi ve yeteneklerine göre seçtikleri kulüplerde alanlarında uzman öğretmenlerce eğitim verilmektedir. Kulüplere sadece o alana yatkın ve yetenekli olanlar alınmamakta, ilgisi ve öğrenme isteği olan öğrencilere de firsat tanınmaktadır. Öğrencilerin etüt kulübüne girmeleri zorunlu olmakla birlikte ayrıca üç kulüp seçme hakkı bulunmaktadır. Her dönemin başında öğrenci kulüp kayıtlarını yenilemekte, eğer isterse farklı kulüpleri seçebilmektedir. Kulüp saatleri pazar günü hariç diğer günlere yayılmakta, öğrenci okul saatlerine uygun bir şekilde kulüplerini tercih edebilmektedir.

Kulüpler dört alt başlık altında toplanabilir;

1. Etüt kulüpleri: Öğrencilerin doğrudan okul derslerine takviye amaçlı kurulmuş kulüplerdir. Öğrenciler, ilgili branş öğretmeniyle soru çözebilir, ödevlerini yaparken yardım alabilir veya anlamadığı konularda destek görebilirler. Başlıca etüt kulüpleri şunlardır; Türkçe, Matematik, Sosyal Bilgiler, Fen Bilimleri, İngilizce, Bilgisayar. 
2. Sosyal kulüpler: Öğrencilerin, yaşadıkları toplumla uyum içinde olmalarını sağlayarak, beraber yaşama, sorumluluk alma, yardımlaşma ve karar verme gibi bilgi, tutum ve becerilerinin gelişimine yönelik faaliyetler gösterirler. Başlıca sosyal kulüpler şunlardır; Edebiyat Basın-Yayın, Gezi, Tarih, Sivil Toplum.

3. Kültür-Sanat kulüpleri: Öğrencilerin, hayal güçlerini ve yaratıcılıklarını geliştirmek, duygu ve düşünceleri farklı şekillerde ifade ederek insanlarla iletişime geçmek, evrensel bir dil yaratmak, estetik duyguların gelişimini sağlamak amacıyla kurulmuşlardır. Başlıca kültür-sanat kulüpleri şunlardır; Müzik, Resim ve El Sanatları, Ebru, Tiyatro, Sinema, Folklor.

4. Sportif kulüpler: Öğrencilerin fiziksel gelişimlerine yardımcı olmak, sorumluluk almak, liderlik yapmak, takım halinde çalışabilmek, koordinasyon, karar verme ve hızlı düşünme gibi becerileri geliştirmek hedeflenmiştir. Başlıca sportif kulüpler şunlardır; Futbol, Voleybol, Basketbol, Taekwondo, İzcilik, Jimnastik, Satranç.

Her kulüp için temel hedef soruları geliştirilmiş ve başarı bu sorular çerçevesinde değerlendirilmektedir. Yapılan çalışmalar bu çerçevede ölçülmeye çalışılmakta ve aileler de bu sorularla ilgili özel bir karne şeklinde bilgilendirilmektedir.

Araştırmanın amaçlarına yönelik öğretmenlere sorulan sorular 1şı̆̆ında ortaya çıkan bulgular aşağıda sunulmuştur.

\section{Değerler eğitimiyle ilgili ne tür uygulamalarınız var? sorusuyla ilgili bulgular}

Öğretmenlerin değerler eğitimiyle ilgili uygulamalarına yönelik elde edilen veriler aşağıdaki tabloda gösterilmiştir;

Tablo 2 .

Uygulamalara İlişkin Kodlar

\begin{tabular}{ll}
\hline \multicolumn{1}{c}{ Kodlar } & f \\
\hline Rehberlik Servisi & 2 \\
Kulüp öğretmenleri & 4 \\
Etüt dersleri & 2 \\
Etkinlikler & 6 \\
Kavramlar & 2 \\
Aile & 2 \\
Kullanılan yöntem ve teknikler & 7 \\
\hline
\end{tabular}

Tablo 2'ye bakıldığında öğretmenlerin değerler eğitiminde kavramlara yönelik uyguladıkları etkinlikler ve bu etkinliklerde kullandıkları çeşitli yöntem ve tekniklerin 
ön plana çıktığı görülmektedir.

Öğretmenlerin bu soruyla ilgili verdikleri cevaplardan bazıları şu şekildedir;

"Değer seçimi, belirli gün ve haftalara paralel şekilde Rehberlik ve Psikolojik Danışmanlık Servisi tarafından hazırlanıyor. Kulüp öğretmenleri hazırlanan konu içeriklerini geliştiriyorlar. Konular derste anlatılıyor, her sınıfın panosu dolduruluyor, konuyla ilgili etkinlikler (resim, afiş, kâğıt katlama, kısa film, animasyon vb.) gerçekleştirilerek konunun öğretilmesine çalış1lıyor.” (Öğrt. 1).

"Etüt dersinde Rehberlik Servisinin verdiği materyaller üzerinden sınıfta bireysel çalışmalar yapılıyor ve ev ödevi veriliyor. Matematik dersinde günlük hayata uygun şekilde konu işlenmeye çalışl1ıyor ve konuyla ilgili soru-cevap şeklinde işleniyor. Gezilerde ise konu uygun mekânda anlatılıyor. Öğrencilere söz hakkı verilip konuşmaları sağlanıyor." (Öğrt. 2).

"Çocukları görsellikle yakalamaya çalışıyoruz. Küçük çocukların görsel hafızalarının daha iyi olduğunu düşünüyorum. Film, afiş, internet, sosyal medya, oyunlar, yarışmalar yapılıyor. Mesela geri dönüşüm atölyesi gerçekleştirildi, tavadan saat, çöp poşetinden çiçek yapıldı, bunlar daha kalıcı oluyor." (Öğrt. 3).

"Her kulüpte o haftanın kavramına göre farklı etkinlikler yapılıyor. Örneğin, Kasım ayının kavramı kitap okuma ve düşünme. Buna göre; İngilizce Kulübü’nde hikayeler okunuyor, Bilgisayar Kulübü'nde e-kitap yarışması, Edebiyat-Basın Yayın Kulübü’nde öykü okuma ve bu öykülerin sonunu öğrencilerin kendilerinin oluşturması, Ebru Kulübü’nde kitap ayracı yapılası, Gezi Kulübü'nde TÜYAP Kitap Fuarı, Süleymaniye Kütüphanesi ve kağıt yapım atölyesi gezileri yapılmakta, Spor Kulüplerinde antrenör kitap okuyarak öğrencilere model olmaya çalışıyor. Böylece bir kavram çoklu zekâ kuramına göre birçok yönden ele alınarak etrafı dolduruluyor.” (Öğrt. 10).

"Öğrencilere verilen kavramla ilgili internetten araştırma yaptırılıyor, bununla ilgili bir sunum ödevi hazırlattırılıyor. Hem bilgisayar becerilerini artırıcı, hem de o haftanın kavramını öğretici etkinlikler birlikte yapılıyor. Word, power point, paint gibi programlarda etkinlikler düzenleniyor. Facebook üzerinden öğrencilerin faaliyetleri sergileniyor." (Öğrt. 8).

"Kavramların seçimi Milli Eğitim müfredatına paralel yapılıyor, kavramlar Rehberlik Servisi'nin de bulunduğu bir komisyon tarafından hazırlanıyor. Kavramların içeriklerinde görsel ve işitsel tüm dokümanlar bu komisyon tarafindan hazırlanıyor. Kavramın nasıl işleneceğini öğretmenler gösteriyor.” (Öğrt. 4).

“Önemli olan 'Bunları nasıl davranışa dönüştürebiliriz?' sorusunun cevabını verebilmek. Bunun için derslerin içine anlatım, uygulama, oyun, video, tiyatro gibi farklı etkinlikler koymaya çalışıyoruz. Aileden gelen davranışlar çok önemli, çocuğun altyapısı önemli, ailede problem varsa bu bize de yansıyor.” (Öğrt. 5). 
"Video, anlatım, konu çalışmaları yapılıyor, çocukların fikirleri alınıyor, neler hissediyor diye soruluyor. Öğrenci kendinden bir şeyler katıyor, bu daha etkili oluyor. Öğrenci daha önce anlatılan bir şeye hemen daha önce anlattınız diyerek geri bildirimde bulunuyorlar." (Öğrt. 6).

“Küçük sınıflarda öğrencilerin kendilerinin hazırladıkları pano çalışmaları, büyük sınıflarda anlatımlar yaptırılıyor.” (Öğrt. 9).

"Verilmek istenen eğitim üçayaklı, öğretmen, öğrenci, veli şeklinde planlanıyor fakat veliye ulaşmak biraz zor. Dersler hem sözel hem de davranışsal olarak işleniyor. Gezi, film, yarışma, sene sonu gösterisi, dergide ayın konusu gibi etkinlikler düzenleniyor ve bunların ağırlıklı öğrenci tarafından yapılmasına gayret ediliyor.” (Öğrt. 7).

\section{Kurum olarak değerler eğitimi ile ilgili hangi açılardan kendinizi farklı görüyorsunuz? sorusuyla ilgili bulgular}

Öğretmenlerin değerler eğitimiyle ilgili kendilerini hangi açılardan farklı gördüklerine yönelik elde edilen veriler aşağıdaki tabloda gösterilmiştir;

Tablo 3'e bakıldığında öğretmenlerin değerler eğitiminde, karşı tutum ve davranışlarında, daha fazla ilgi göstermelerinde ve değerlerin işlenmesine yönelik kavramların ele alınmasında kendilerini farklı görmelerinin ön plana çıktığ görülmektedir.

Tablo 3.

Farklılıklara İlişkin Kodlar

\begin{tabular}{|c|c|}
\hline Kodlar & $\mathbf{f}$ \\
\hline Değerler & 2 \\
\hline Kulüpler & 3 \\
\hline Mezunlar & 1 \\
\hline Kavramlar & 2 \\
\hline İlgi & 4 \\
\hline Öğretmenlerin tutumu & 5 \\
\hline
\end{tabular}

Öğretmenlerin bu soruyla ilgili verdikleri cevaplardan bazıları şu şekildedir;

“MEB'de senelik 10 tane değer oluyorsa biz de 30 tane değer işleniyor. Her kulüp aynı değeri işlediği için çocuğun zihninde daha çok yer etmesi ve çocuğu kuşatması sağlanıyor. Ayrıca süre olarak da daha uzun süre işleniyor. Bir de mezunlarımızı mümkün olduğunda izlemeye, onlarla irtibatı kesmemeye çalışıyoruz.” (Öğrt. 1). 
“Çocuklarla daha fazla birebir ilgileniliyor.” (Öğrt. 2).

"Fark1, ortak bir kavramın her yönüyle işlenmesi olabilir. Kurumun MEB'den daha farklı algılanması, ortamı daha sıcak bulmaları, öğretmenlerin daha candan olması, ortamı sevmeleri ders olmasa da gelmeleri. Okulla benzerlikler, örneğin zil çalıyor, öğretmen var, ders var, etüt var, ödev veriliyor. Buna karşın k1lık-kıyafet zorunluluğu yok, sınav ve not yok, okulda anlayamadığını burada öğrenince buraya bağlanıyor ve okulda daha faydalı oluyor, öğrencilerden bir ücret alınmıyor.” (Öğrt. 3).

"Daha fazla detaya iniliyor ve verilenler burada yaşanılıyor. Öğretmene her açıdan materyal sağlanıyor.” (Öğrt. 4).

"Okullarda daha uzun zaman ayrılıyor, örneğin sevgi kavramı üç ay işleniyor. Bizde ise daha kısa sürede daha fazla kavram işleniyor. Okullarda kavram bazı derslerde işlenirken, bizde bütün kulüplerde müfredata yedirilmişs şekilde uygulanıyor. Ayrıca bizde kavramların farklı alt başlıkları da işleniyor." (Öğrt. 5).

"Bu kurumda amaç sadece öğretim yapmak değil, gerçekten eğitim vermeye, çocukları eğitmeye çalışıyoruz. Gönüllülük ve çocuklara bağlılık bizim farkımız olabilir." (Öğrt. 6).

“MEB'de öğretmenler sadece verilenleri prosedür icabı, görev olarak yapıp baştan savabiliyorlar. Verdikleri değerler ile yaşamları çelişebiliyor. Burada ise öğretmenler seçilerek alınıyor, verdiği değerleri yaşamaya gayret ediyorlar, gönül bağları var. Ayrıca burası daha butik olduğu için hızlı işliyor." (Öğrt. 7).

\section{Verdiğiniz değerler eğitiminin geri bildirimini nasıl alıyorsunuz? sorusuyla ilgili bulgular}

Öğretmenlerin değerler eğitimiyle ilgili geribildirim almalarına yönelik elde edilen veriler aşağıdaki tabloda gösterilmiştir;

Tablo 4'e bakıldığında öğretmenlerin değerler eğitimine yönelik yaptıkları ile ilgili geribildirimleri öncelikle velilerden ve öğretmen gözlemlerinden aldıkları görülmektedir.

Öğretmenlerin bu soruyla ilgili verdikleri cevaplardan bazıları şu şekildedir; 
Tablo 4.

Geribildirimlere İlişkin Kodlar

\begin{tabular}{ll}
\hline \multicolumn{1}{c}{ Kodlar } & f \\
\hline Anketler & 2 \\
Veliler & 5 \\
Öğretmen gözlemleri & 4 \\
Öğrenciler & 2 \\
Mezunlar & 1 \\
Çevre & 1 \\
\hline
\end{tabular}

“Her sene öğrencilere 'Sen olsan...' anketi ile ailelere Veli Memnuniyet Anketi ve Değer Aktarımı Anketi uygulanıyor. Ailelere örneğin, saygı konusunda nasıldı ne oldu şeklinde sorular soruluyor. Haftalık değerler toplantısında öğretmenler gözlemlerini aktarıyorlar, bunlar değerlendiriliyor. Örneğin, Seyirci Kalamayız kampanyasında, Van Depremi ve Suriyeli Çocuklarla ilgili kıyafet, oyuncak, gıda toplandı, kermes düzenlendi, yardımseverlik, şefkat, paylaşma duygularının arttığı ile ilgili, Yaşlılar Haftasında huzurevi gezisi sonrasında olumlu geri bildirimler aldık.” (Öğrt. 10).

“Geri bildirim için öğrenciden soru sormasını, mini rapor veya günlük tutmasını istiyoruz. Günlük hayattaki olaylarla ilgili özeleştiri yapmalarını sağladığımızda, nedenselliğini açıklayıp, duygu dünyalarına hitap edince etkileniyorlar.” (Öğrt. 9).

“Gözlem yaparak geri bildirim alabiliyoruz. Çocukta değişim fark edilebiliyor, girişi, çıkışı, sabah günaydın deyişi, oturup kalkması, öğretmenle iletişiminde gözlemlenebilir fark oluyor. Az veya çok değişim gözleniyor, değişimin olmadı̆̆ı çocuklarda ile problemleri ön plana çıkıyor." (Öğrt. 8).

"Velilerle ilk görüşmede 'evde çocuğunuzun davranışlarında olumlu gelişmeler oldu mu?' diye soruluyor. Örneğin, 8. sınıfa giden bir kız ögrenci, babası yoktu, annesi kızındaki okul başarısı ve ahlaki gelişiminden memnun kaldığını belirtip teşekkür etmişti.” (Öğrt. 1).

"Dönem başında ve sonunda -öntest-son test gibi- Sen olsan? anketi uygulaniyor. Öğrencileri rehberlik servisi de takip ediyor, velilerle görüşmeler yapıyorlar. Mezunlar da takip ediliyor. Örneğin, bir öğrenci babasını kaybetmişti, bunalımdaydı, intiharı düşünüyordu. 'Ben burada olmasaydım çok farklı bir yerde olurdum, bana dokunuşunuz beni çok etkiledi' şeklinde ifade etmişti. $\mathrm{Bu}$ öğrencimiz şu anda üniversitenin son sınıfında okumakta. Örneğin bir başka öğrencimiz, sınıf düzenini bozan çok yaramaz bir çocuktu, şu anda davranışlarında düzelme görülüyor.” (Öğrt. 5). 
"Veli toplantılarında veliler, 'biz buradan çok memnunuz, çocuklarımız güler yüzlü karşılanıyor, ödevlerine yardım ediliyor, kendilerini güvende hissettiklerini söylüyorlar' şeklinde ifade ediyorlar." (Öğrt. 6).

"Değer eğitiminde uzun vadede sonuç alındığı için ailelerden bir anda geri bildirim alınamayabiliyor. Öğretmenlerin çocuk üzerindeki değerlendirmeleri alınıyor. Bir de sokağa bakmak gerekiyor. Bilgi Merkezi geldikten sonra mahallede ne değişmiş? Halkın izlenimi nasıl? Örneğin, köşede takılan çocuk sayısı azalmış, İlçe Emniyet Müdürünün söylemiyle bu mahallede suç oranı azalmış.” (Öğrt. 7).

"Konuyla ilgili iki örnek vereyim. Birincisi, 3. sınıfta erkek bir öğrenci, bize geldiğinde içekapanık ve hiç konuşmuyordu, sınıfta hiçbir şey söyleyemiyordu. Şu an da 6. sınıfta ve sosyalleşti. İkincisi ise, 4. Sınıfa giden erkek bir öğrenci, iki kardeşler. Baba kumarbaz, evdeki her şeyi satıyor, eve gelmiyor, küçük kardeşte iletişim bozukluğu var, sıra altında oturuyor, göz teması kuramıyor, vücudunu başka tarafa çeviriyor, babadan dayak yiyor ve ısırma davranışı görülüyor. Ağabey kardeşine her şeyin güzel olduğunu anlatıyor, burada onu kimsenin dövmeyeceği, onu dinleyeceği söyleniyor. Bu kabul ve güvenle çocukta ciddi gelişmeler olmuştu.” (Öğrt. 2).

“Geri bildirimde çocukların söyledikleri önemli çünkü çocuklar yaşadıklarını anlatıyorlar, politika yapmadan doğrudan söylüyorlar.” (Öğrt. 3).

\section{Değerler eğitimi ile ilgili yaşadığınız zorluklar nelerdir? sorusuyla ilgili bulgular}

Öğretmenlerin değerler eğitimiyle ilgili yaşadıkları zorluklara yönelik elde edilen veriler aşağıdaki tabloda gösterilmiştir;

Tablo 5'e bakıldığında öğretmenlerin değerler eğitiminde yaşadıkları zorluklara yönelik öğretmenlerin idealist ve kaliteli olmaları ile sürekli yeni öğrencilerin uzun süreli katılımlarının olmamasının ön plana çıktığı görülmektedir.

Öğretmenlerin bu soruyla ilgili verdikleri cevaplardan bazıları şu şekildedir;

Tablo 5 .

Zorluklara İlişkin Kodlar

\begin{tabular}{ll}
\hline \multicolumn{1}{c}{ Kodlar } & f \\
\hline Derslere entegrasyon & 2 \\
Öğrencinin süreksizliği & 3 \\
Zaman kısıtlaması & 1 \\
Çevre ile tutarsızlık & 2 \\
Öğretmen kalitesi & 3 \\
Kuşak çatışması & 1 \\
\hline
\end{tabular}


"Öğretmenlerin değerleri derslerine entegre etmede zorluklar yaşanabiliyor, örneğin, sanat ve spor. Eskiden değer bazlı birçok etkinlik karışık veriliyordu, şimdi ise her kulübe uygun en az iki-üç etkinlik verilerek öğretmenlerin bir şey bulamadım bahanesine sığınmalarının kapısı kapatılmış oluyor.” (Öğrt. 1).

"Öğrenci sirkülasyonu çok fazla ve üst kademeye geçiş az olduğundan öğrencilere uzun ve etkili bir eğitim sağlamakta zaman zaman zorlanılmaktadır.” (Öğrt. 10).

"Zaman darlığı sebebiyle daha çok anlatmak ve ayrıntıya girmek zor oluyor.” (Öğrt. 2).

"Burada yapılanların ailede ve sokakta karşılı̆̆ının olmaması en büyük zorluklardan biri. Örneğin, kurumda küfürlü konuşmaya veya akran şiddetine asla izin verilmiyor ama dışarıda bu uygulanmıyor. Öğrenci kurumda küfür etmiyor, ederse özür diliyor fakat toplumun her kesimince kuşatılması gerekiyor. Okulda öğretmenler de küfrediyor." (Öğrt. 4).

"Uygulamada öğretmenlerle yaşanan zorluklar var. Esasında tüm bu yapılanlar öğretmenin bilgi, beceri, aktarma kapasitesiyle ilgili. Sistem öğretmenin üzerine kurulu, öğretmen iyi model olursa, idealistse, gerçekten istiyorsa bu işler ilerliyor.” (Öğrt. 3).

"Çok fazla çocuk sirkülasyonu var, elimizden çok çocuk geçiyor, kısa süreli devamlar fazla olduğundan hepsine ulaşmakta zorluk çekiyoruz. Bazı branşlarda aktarım zor olabiliyor, sınıfta daha kolay, materyal kullanabiliyorsunuz. Bu da öğretmenin becerisiyle orantıl1.” (Öğrt. 5).

"Öğretmen ile öğrenci arasında kuşak farkı var. Bu nesil bilgisayar kuşağı, yozlaşmış kültürün zorluklarını yaşıyor. Örneğin, selamlaşma öğretilirken çocuk 'Neden tanımadıklarıma selam vereyim ki?' diyor, burada kavramlar üzerindeki iki neslin algı farklılıklarını görebiliyoruz." (Öğrt. 7).

\section{Değerler eğitimi ile ilgili öğretmenlere ve kurumlara tavsiyeleriniz nelerdir? sorusuyla ilgili bulgular}

Öğretmenlerin değerler eğitimiyle ilgili tavsiyelerine yönelik elde edilen veriler aşağıdaki tabloda gösterilmiştir;

Tablo 6'ya bakıldığında öğretmenlerin değerler eğitimindeki tavsiyelerine bakıldığında öğretmenin rol model olması, kalitesi, zihniyeti, tutum ve davranışları ön plana çıktığı görülmektedir.

Öğretmenlerin bu soruyla ilgili verdikleri cevaplardan bazıları şu şekildedir; 
Tablo 6 .

Tavsiyelere İlişkin Kodlar

\begin{tabular}{ll}
\hline \multicolumn{1}{c}{ Kodlar } & f \\
\hline Öğretmen zihniyeti & 3 \\
Değerlerin yaşanması & 1 \\
Aile katılımı/desteği & 2 \\
Etkinlik zenginliği & 2 \\
Öğretmen kalitesi & 4 \\
Yöntem & 3 \\
Rol model olmak & 3 \\
\hline
\end{tabular}

"Değerler eğitimini öğretmen zihnen kabullenmezse ve özümsemezse kendisine etkinlik bulması da zorlaşıyor. İlk zamanlarda çok zor zannediliyor halbuki çocuk maç yaparken faul yaptığında öğretmen centilmenlik, saygı gibi kavramları hemen o anda verebilir. Kurumlar, öğretmenleri besleyecek kaynakları (kitap, dergi, CD, vb.) çokça bulundurması gerekebilir. Kurum kendi içinde değer kültürünü yaşaması gerekir, tüm çalışanların bunu uygulaması, rol olması gerekir. Değer aktarımında geziler, kısa filmler, animasyonlar, yerinde yaşamak etkili oluyor, bunlara dikkat edilebilir. Aileyi bu sürece katmak gerekir, biz veli toplantıları, seminerler, aile bülteni, aile görüşmeleri, danışmanlık hizmetleri vererek ailelerle sürekli iletişim halinde olmaya çalışıyoruz." (Öğrt. 1).

“Öğrencilerin duygu dünyalarına dokunmak, örneğin, film izlenirken durdurup konuyla ilgili yorum yapmak, öğrencilere örnek olmak gerekir. Kurumların değerlerle ilgili ayrı bir uzman öğretmeni görevlendirmeli, atölye çalışmaları vb. etkinlikler yapılmalı." (Öğrt. 2).

"Personel seçimiyle bu iş başlıyor. Dert edinmişlerle bu iş yapılmalı. Öğretmenler materyal olarak desteklenmeli. Öğretmenler araştırmalı, yenilikleri takip etmeli, daha iyi nasıl anlatırım diye kafa yormalı." (Öğrt. 3).

"Her şey öğretmende bitiyor, öğretmen seçimi çok önemli, donanımlı, gönül veren kişiler olmalı. Etkin hizmet içi eğitimler yapılmalı, seminer şeklinde değil, paket program veya okul şeklinde." (Öğrt. 4).

“Anlatarak değer aktarılır mı? Bu sebeple uygulamaya dökülmesi lazım. Öğrenci bunu içselleştirebiliyor mu? Bunun için öğrencilere görev ve sorumluluklar verilmeli, örneğin diş firçalama gibi. Eğer ailede bu kavram oturmamışsa burada anlatmanın önemi olmuyor, örneğin eşler arası saygı. Aile ile işbirliği yapıp, dahil etmezsen çocuğun sadece aklının bir köşesinde kuru bilgi olarak kalıyor.” (Öğrt. 8). 
"Piyasada çok materyal ve yayın var, öğretmenlerin bunları takip etmesi onların ufuklarını açacaktır. Biz eskiden kendi materyalimizi kendimiz oluşturuyorduk, kaynak sıkıntısı çekiyorduk. Öğretmenin kendi becerisi çok önemli, bunu dert edinmeli ve kendini sürekli geliştirmeli. Kurum yönetimi ise öğretmenlere kaynak ve hizmet içi eğitim olanakları sağlamalı." (Öğrt. 5).

“Öncelikle öğretmenin yaşaması gerekiyor, önce istenilen davranışı biz göstermeliyiz, gerçekten istemeliyiz, bizim doğalımız olmalı.” (Öğrt. 6).

“Öğretmen çocuğu anlamaya çalışmalı, çocuktan bir şey öğrenebilmeli. Araştırmalı, ben bu konuyu daha iyi nasıl anlatırım demeli, başkalarıyla istişare etmeli. Kurumlar, lokal düzeyde, mahalle olarak bir araya gelip ortak bir dil kullanmalı, ortak bir yol haritası çıkarmalı. Örneğin, En önemli sorun ne? Ne yapabiliriz? soruları karşısında diyalogla çözüm üretilmeli.” (Öğrt. 9).

Öğretmenlerle yapılan birebir görüşmeler sonucunda elde edilen bulgular sonucunda üç temanın baskın bir şekilde ön plana çıktığı görülmektedir;

1. Değerler eğitiminde öğretmenin rolü,

2. Değerler eğitiminde kullanılan yöntemlerin rolü,

3. Değerler eğitiminde ailenin rolü.

\section{Sonuç ve Tartışma}

Değerler, kültür ve topluma anlam ve önem veren ölçütlerdir (Fichter, 2006, s. 167). Her toplumun kendine has değerleri vardır ve toplumda nitelikli vatandaşlar yetiştirmek, okullarda değerler eğitiminin verilmesi ile mümkündür (Aspin, 2000, s. 197). Değerler eğitimi, kısaca değer kazandırma etkinliğidir, bir başka deyişle değerlerin açık bir şekilde öğretilmesidir (Hökelekli ve Gündüz, 2007, s. 384). Değerler eğitiminde okulların yetersiz kaldığı noktada insanlar farklı kurumlara müracaat ederek çocukları için farklı alternatifler aramaktadırlar. Bu alternatif kurumlardan birisi de İstanbul Bayrampaşa Bilgi Merkezidir. Bilgi Merkezi, değer aktarımını eğitim misyonunun ilk sırasına koyarak ilköğretim çocuklarına yönelik eğitim-öğretim faaliyetlerini sürdürmektedir.

Değer aktarımı yaklaşımının temelinde, yetişkinlerin çocuklara ahlaki değerleri doğrudan öğreterek, onların davranışlarını şekillendirme ve iyi alışkanlıklar kazandırma görev ve sorumluluğu olduğu inancı yatmaktadır (Helsteat ve Taylor, 2000; akt. Doğanay, 2007, s. 267). Değer aktarımının hedefi, yerleşik görüşleri kullanarak uyumluluğu gerçekleştirmektir. Belli görüşlerin ahlaki niteliği kanıtlanmış olarak kabul edilir ve bu durum onların aktarılmasını doğrudan meşrulaştırır. Öğrenme sürecinin yönetilmesi yani amaçlanan motivasyonun içeriği ve gencin benimsediği tavırlar öğretmeni tarafindan yapılan tercih yoluyla önceden belirlenir. Fiili durum değerlerin çoğulculuğunun gündeme getirilmediğini, çünkü öğrencilerin seçiminin onlar için yapılan seçimler olarak görüldüğünü ortaya koymaktadır (Ziebertz, 2007, s. 455- 
461). Bu yaklaşımda, öğretilmesi istenilen değerlerle tutarlı bir davranış göstermesi için bireylere aşağıdaki beş basamaklı işlem uygulanır (Doğanay, 2007, s. 268); (1) Amacın belirlenmesi, (2) Ölçütün belirlenmesi, (3) Uygulanacak yöntemi seçme, (4) Seçilen yöntemin uygulanması, (5) Seçilen yöntemin değerlendirilmesi ve gerektiğinde de tekrar edilmesi.

Bu araştırmada ortaya çıkan temalar aşağıda ele alınarak tartışılmıştır;

\section{Tema 1: Değerler eğitiminde öğretmenin rolü}

Öğretmen, okulda verilen eğitim sisteminin en temel öğesidir. Öğretmenler toplumların gerçek mimarları ve insan kişiliğini şekillendiren gerçek sanatkârlardır (Özden, 2002, s. 9). Çocuk için öğretmen; eğiten, öğreten, dostluk gösteren, seven kısacası kişilik gelişiminin temellerini atan insandır (Oktay, 1999, s. 218-219). Çocuk, değerleri öğretmenle sevmekte ve onunla bütünleştirmektedir. Sevgiyi, saygıyı, yardımlaşmayı, paylaşmayı ve dostluğu öğretmeninden görecek ve gelecek yaşamındaki davranışlarında bu özellikleri göstermeye devam edecektir (Yazar ve Erkuş, 2013, s. 198).

Değerler eğitiminde öğretmenin başrolde olduğunu Öğretmen 3 "Esasında tüm bu yapılanlar öğretmenin bilgi, beceri, aktarma kapasitesiyle ilgili. Sistem ögretmenin üzerine kurulu, ögretmen iyi model olursa, idealistse, gerçekten istiyorsa bu işler ilerliyor" cümlesiyle ifade etmiştir. Aynı şekilde Öğretmen 5 de öğrencilere yapılmak istenen aktarımın öğretmenin becerisiyle orantılı olduğunu "Bazı branşlarda aktarım zor olabiliyor, sinıfta daha kolay, materyal kullanabiliyorsunuz. Bu da ögretmenin becerisiyle orantılı" şeklinde belirtmiştir.

Öğretmenlerin seçilerek bu göreve getirilmeleri gerektiğini savunan Öğretmen 3 duygularını şu şekilde ifade etmektedir; "Personel seçimiyle bu iş başllyor. Dert edinmişlerle bu iş yapılmalı. Öğretmenler araştırmall, yenilikleri takip etmeli, daha iyi nasil anlatırım diye kafa yormalı."

Öğretmenin her şeyden önce, öğrettiği ile yaşadığı arasında tutarlılık olmalıdır. Öğrettiği değerleri öncelikle kendisi yaşamalıdır. Öğretmen 7 bu konuda şöyle demektedir; "MEB'de ögretmenler sadece verilenleri prosedür icabı, görev olarak yapıp baştan savabiliyorlar. Verdikleri değerler ile yaşamları çelişebiliyor. Burada ise ögretmenler seçilerek alınıyor, verdiği değerleri yaşamaya gayret ediyorlar, gönül bağlart var." Öğretmen 6 da aynı şekilde "Öncelikle öğretmenin yaşaması gerekiyor, önce istenilen davranışı biz göstermeliyiz, gerçekten istemeliyiz, bizim doğalımız olmalı." cümlesiyle düşüncelerini dile getirmektedir.

Öğretmenlerin gönülden isteyerek, amatör bir ruhla çalışmaları gerektiğini Öğretmen 6 "Bu kurumda amaç sadece öğretim yapmak değil, gerçekten eğitim vermeye, çocuklar eğitmeye çalışıyoruz. Gönüllülük ve çocuklara bă̆lılık bizim farkımız olabilir" cümleleriyle ifade etmektedir. Aynı şekilde Öğretmen 4 de "Her şey ögretmende bitiyor, 
ögretmen seçimi çok önemli, donanıml, gönül veren kişiler olmalı" cümlesiyle bu konuya destek vermektedir.

Öğretmenin sahip olması gereken özellikler olarak aşağıdaki özelliklere vurgu yapılmıştır;

“Öğrencilerin duygu dünyalarına dokunmak” (Öğrt. 2),

"Değerler eğitimini öğretmen zihnen kabullenmezse ve özümsemezse kendisine etkinlik bulması da zorlaşlyor" (Öğrt. 1),

“Öğretmenlerin daha candan olması" (Öğrt. 3),

"Öğretmen çocuğu anlamaya çalışmalı, çocuktan bir şey öğrenebilmeli. Araştırmalı, ben bu konuyu daha iyi nasıl anlatırım demeli, başkalarıyla istişare etmeli” (Öğrt. 9).

Kazanılan değerlerin kolay unutulmaması, tam ve kullanılabilir nitelik taşıması, öğrenenin kişiliğinin bir parçası haline gelmesi ile mümkündür. Böylesi bir öğrenme de öğrencinin kendi öğrenme yaşantısı içinde kazanılabilir. Öğrencinin öğrenme yaşantısı, gerçek yaşantı koşullarına dönüşmedikçe beklenen nitelikte bir öğrenme gerçekleşemez (Ercan, 1999, s. 31). Etkin bir öğrenmeyi sağlamada öğretmenin yeri ve rolü büyüktür. Öğretmenlerin bu söylemlerinden de anlaşılacağ gibi değerler eğitiminde kilit rol oynayan öğretmenlere büyük sorumluluklar düşmektedir. $\mathrm{Bu}$ sorumlulukların en büyüklerinden birisi de öğrencilere rol model olmaktır. Öğrenciler öğretmenlerinin, giyimlerini, konuşmalarını, hal ve hareketlerini, problem çözme yöntemlerini, bakış açılarını, olaylara yaklaşım tarzlarını, iletişim biçimlerini, kişiliklerini örnek almaktadırlar.

\section{Tema 2: Değerler eğitiminde kullanılan yöntemler}

Değerlerin davranışlara yansıması için kullanılan öğretim yöntemleri önem kazanmaktadır. Anlatım yöntemiyle öğrenciyi bilgilendirmek mümkün olsa da değerleri kazandırmak ve içselleştirmek için daha aktif ve farklı öğretim yöntemlerinin kullanılması gerekmektedir. Geçmiş yıllarda eğitim programlarında dolaylı olarak verilen değerleri, günümüzde ünite kazanımlarıyla birlikte doğrudan verme yöntemleri benimsenmiştir. Değer öğretimi yöntemlerinden en yaygın kullanılanları "değer telkini, değer açıklaması, değer analizi ve ahlaki muhakemedir."

Değer telkini yaklaşımında, "insan zihnine sürekli tekrar ve tavsiyelerle etkide bulunulduğunda birey, onu kabul edecek ve ona göre davranacaktır" görüşü hâkimdir (Whitney, 1986, s. 66). Değer açıklaması yaklaşımında ise telkin yaklaşımının aksine öğrencilere belirli değerleri vermeden onlarda var olan değerleri açığa çıkarmaları ve kendi değerlerini fark etmeleri amaçlanmaktadır. Mantıklı düşünme ve muhakemeyi vurgulayan değer analizi yaklaşımında da öğrenciler, araştırma veya değer konularının doğrulukları hakkında kanıtlanabilir gerçekler elde etmeye teşvik edilmektedir (Huitt, 2004, s. 6-7). Ahlaki muhakeme yaklaşımında ise Kohlberg ve Piaget tarafından oluşturulan ahlaki gelişism basamakları yeniden tanımlanmıştır (Selçuk, 2005, s. 112). 
Kullanılan yöntemlerle ilgili öğretmenlerin bazı açıklamaları şu şekildedir;

Öğretmen 3, “Çocukları görsellikle yakalamaya çalışıyoruz. Küçük çocukların görsel hafizalarının daha iyi olduğunu düşünüyorum. Film, afiş, internet, sosyal medya, oyunlar, yarışmalar yapılıyor. Mesela geri dönüşüm atölyesi gerçekleştirildi, tavadan saat, çöp poşetinden çiçek yapıldı, bunlar daha kalıcı oluyor" cümleleriyle çocuklara ulaşmada daha çok görsel yöntemlerin etkili olacağını belirtmektedir.

Öğrencilere çoklu zekâ kuramı temel alınarak eğitim verilmektedir. Bu yaklaşımın nasıl uygulandığını Öğretmen 10 şöyle ifade etmektedir; "Her kulüpte o haftanın kavramına göre farkl etkinlikler yapılıyor. Örneğin, Kasım ayının kavramı kitap okuma ve düşünme. Buna göre; Ingilizce Kulübü'nde hikâyeler okunuyor, Bilgisayar Kulübü'nde e-kitap yarışması, Edebiyat-Basın Yayın Kulübü'nde öykü okuma ve bu öykülerin sonunu ögrencilerin kendilerinin oluşturması, Ebru Kulübü’nde kitap ayracı yapılması, Gezi Kulübü'nde TÜYAP Kitap Fuarı, Süleymaniye Kütüphanesi ve kâğıt yapım atölyesi gezileri yapılmakta, Spor Kulüplerinde antrenörler kitap okuyarak ögrencilere model olmaya çalışıyorlar. Böylece bir kavram çoklu zekâ kuramına göre birçok yönden ele alınarak etrafi dolduruluyor."

Öğrencilere model olma gerekliliğini Öğretmen 6 “Öncelikle öğretmenin yaşaması gerekiyor, önce istenilen davranışı biz göstermeliyiz, gerçekten istemeliyiz, bizim doğalımız olmalı” şeklinde dile getirmiştir.

Öğretmen 2 "Çocuklarla daha fazla birebir ilgileniliyor" demekle öğrencilerle birebir ilgilenmenin önemini ve her öğrencinin öğrenme kapasitesi ve hızı farklı olduğu düşünülürse bunu yapmanın gerekli bir yöntem olduğunu belirtmektedir.

Öğrencilere sürekli yapılan geri bildirim yönteminin onları geliştireceğini Öğretmen 9 "Geri bildirim için ögrenciden soru sormasını, mini rapor veya günlük tutmasını istiyoruz. Günlük hayattaki olaylarla ilgili özeleştiri yapmalarını sağladığımızda, nedenselliğini açıklayıp, duygu dünyalarına hitap edince etkileniyorlar" cümleleriyle belirtmektedir.

Ahlak ve karakter eğitiminde bireyin ahlakî muhakeme yapması veya değerleri üzerine düşünmesi yerine toplumsal hayatın devamı için elzem olan sorumluluk, saygı, adil olma, güvenilirlik gibi temel ahlakî davranışların doğrudan ya da dolaylı olarak öğretilmesi ve alışkanlıklar kazandırılması zorunlu görülmektedir. Ahlakî muhakeme, değer açıklama ve değer analizi yaklaşımlarında ise bireyin değerleri üzerine düşünmesi, değerlerin toplumsal yaşamdaki işlevlerini fark etmesi kısaca bilişsel süreçlerini kullanması gerekir (Akbaş, 2008). Değerler, eğitim programlarının hem açık hem de örtük amaçları arasında yer alan önemli unsurlardır. Değer eğitimi okullarda planlı öğrenme etkinlikleri ile gerçekleştirilebilirken, okulda ve sınıfta yaratılan kültürel ortam ile öğretmenlerin neyi iyi, neyi kötü olarak tanımladıkları öğrenciler için örtük değer eğitimini oluşturmaktadır (Demirel, 2009). 


\section{Tema 3: Değerler eğitiminde ailenin rolü}

Değerler aileden, yakın çevreden, yazılı ve görsel materyallerden taklit, model alma ya da okuma yolu ile öğrenilmektedir (Şen, 2008, s. 764-765). Değerler eğitiminde olması ve desteklenmesi gereken bir diğer sacayağının aile olduğu öğretmenlerce dile getirilmiştir. Ailenin rolüyle ilgili öğretmenlerin bazı açıklamaları şu şekildedir;

Öğretmen 1 “Aileyi bu sürece katmak gerekir, biz veli toplantılart, seminerler, aile bülteni, aile görüşmeleri, danışmanlık hizmetleri vererek ailelerle sürekli iletişim halinde olmaya çalışıyoruz" cümleleriyle ailenin sürece katılması gerektiğini vurgulamıştır.

Yapılan eğitimin ailede bir karşılığının olması gerektiğini Öğretmen 8 şöyle ifade etmektedir; "Eğer ailede bu kavram oturmamışsa burada anlatmanın önemi olmuyor, örneğin eşler arası saygl. Aile ile işbirliği yapıp, dahil etmezsen çocuğun sadece aklının bir köşesinde kuru bilgi olarak kalıyor." Öğretmen 4 de kurum ile ailenin paralel hareket etmesi gerektiğini dile getirmektedir; "Burada yapılanların ailede ve sokakta karşılı̆̆ının olmaması en büyük zorluklardan biri. Örneğin, kurumda küfürlü konuşmaya veya akran şiddetine asla izin verilmiyor ama dışarıda bu uygulanmıyor. Ö̆̆renci kurumda küfür etmiyor, ederse özür diliyor fakat toplumun her kesimince kuşatılması gerekiyor."

Öğretmen 5 değerler eğitiminde temelin aile tarafından atıldığını şöyle ifade etmektedir; "Aileden gelen davranışlar çok önemli, çocuğun altyapısı önemli, ailede problem varsa bu bize de yansiyor."

Öğretmen 7 "Verilmek istenen ĕgitim üçayakl, öğretmen, ögrenci, veli şeklinde planlanıyor fakat veliye ulaşmak biraz zor" şeklindeki ifadesiyle ailelere ulaşmanın zorluğunu ifade etmektedir.

İnsanlar değer ve inançlarını çevrelerindeki diğer insanlardan öğrenir ve bu değerleri davranışlarına yansıtırlar. Anne-babalar çocuklarının ahlaki eğitiminden birinci derecede sorumluyken, okul da aileden sonra toplumsal değerleri öğreten önemli bir kurum olarak karşımıza çıkmaktadır. Öğretmenler bilinçli ya da bilinçsiz bir şekilde değerleri öğrencilerine aktarırlar (Coombs-Richardson ve Tolson, 2005). Değer eğitiminin öğrencilerin yaşamında daha anlamlı ve kalıcı olması için okulun yanında aile ve çevre tarafından desteklenmesi gerekir. Değer eğitimi ile öğrenciler iyi-kötü, doğru-yanlışı anlayabilmektedirler. Bu anlamlandırmanın sonucunda olumlu aile, sınıf, okul ortamı ve toplum gelişmektedir.

\section{Öneriler}

$\mathrm{Bu}$ araştırmada elde edilen veriler ışığında aşağıdaki önerilerde bulunulabilir;

1. Değer aktarımındaki en önemli rol model öğretmen olduğundan, öğretmenlerin eğitim ve kişisel gelişimlerine sürekli yatırım yapılmalıdır. 
2. Değerlerin içselleştirilmesi için öğrencilere yönelik daha aktif ve farklı öğretim yöntem ve teknikleri kullanılmalıdır.

3. Değer ediniminde ailelerin çocuklarını sürekli desteklemeleri ve okul-aile işbirliğinin sürdürülmesi esastır.

4. Değer eğitiminde hem planlı ve açık olan programlardan hem de örtük programlardan yararlanılmalıdır.

5. Değer eğitiminde mümkün olduğunca okul-sınıf-ev ortamının birbiriyle tutarlı olması ve pozitif bir iklime sahip olması gerekmektedir.

\section{Kaynakça}

Akbaş, O. (2008). Değer eğitimi akımlarına genel bir bakış. Değerler Ĕ̆itimi Dergisi, 6(16), 9-27.

Aspin, D. N. (2000). Values, beliefs and attitudes in education: the nature of values and their place and promotion in schools. Education, Culture and Values, 14, 197-218.

Aydın, İ. (2006). Eğitim ve ögretimde etik. Ankara: Pegem A Yayıncılık.

Coombs-Richardson, R. \& Tolson H. (2005). A comparison of values rankings for selected American and Australian teachers. Journal of Research in International Education, 4, 263-277.

Costa, P. T. Jr., \& McCrae, R. R. (2001). A theoretical context for adult temperament. T. D. Wachs, \& G. A. Kohnstamm (Eds.), Temperament in Context içinde (s. 1-21). Mahwah, NJ: Lawrence Erlbaum.

Çağlar, A. (2005). Okul öncesi dönemde değerler eğitimi. Erken Çocuklukta Gelişim ve Eğitimde Yeni Yaklaşımlar 2. (Ed. M. Sevinç). İstanbul: Morpa Yayınları.

Çalık, E. (2008). İlköğretim öğrencilerinin iyimserlik düzeylerinin ve okul ilişkin algılarının incelenmesi. Yüksek Lisans Tezi. Ankara Üniversitesi, Eğitim Bilimleri Enstitüsü, Ankara.

Demirel, M. (2009). A review of elementary education curricula in Turkey: Values and values education. World Applied Sciences Journal, 7(5), 670-678.

Demirel, Ö. (Ed.), Kaya, Z. (Ed.) (2009). Eğitim bilimine giriş. Ankara: Pegem A Yayıncılık.

Doğanay, A. (2007). Değerler eğitimi. (Ed. C. Öztürk). Hayat Bilgisi ve Sosyal Bilgiler Öğretimi Yapılandırmacı Bir Yaklaşım. (3.basım). Ankara: Pegem-A Yayıncılık, 255-286.

Ercan, A. R. (1999). Öğretmen davranışları. Ankara.

Fichter, J. (2006). Sosyoloji nedir? (Çev. Nilgün Çelebi). Ankara: Anı Yayıncılık.

Güngör, E. (2000). Değerler psikolojisi üzerine araştırmalar (3. basım). İstanbul: Ötüken Yayınları.

Hökelekli, H. ve Gündüz, G. (2007). Üstün Yetenekli Çocukların Değer Yönelimleri ve Eğitimleri. Değerler ve Eğitimi Uluslararası Sempozyumu, İstanbul: Değerler Eğitimi Merkezi Yayınları, s. 371-396.

Huitt, W. G. (2004). Values. Educational Psychology Interactive, Voldosta State University. http:// chiron.valdosta.edu/whuitt/col/affsys/values.htm. (Erişim tarihi: 22.05.2018). 
Kılıç, E. (1983). Yaygın eğitim. Cumhuriyet Döneminde Eğitim. MEB Yayınları 91, Ankara, s. 472.

Köknel, Ö. (2007). Çatışan değerlerimiz: aileden topluma, politikadan inançlara, sevgiden aşka kadar. İstanbul: Altın Kitaplar Yayınevi.

Oktay, A. (1999). Yaşamın sihirli yılları: Okul öncesi dönem. İstanbul: Epsilon Yayıncılık.

Özdemir, M., Kalaycı, H. (2013). Okul bağlılığı ve metaforik okul algısı üzerine bir inceleme: Çankırı örneği. Kuram ve Uygulamada Eğitim Bilimleri Dergisi, 13(4), 2125-2137.

Özden, Y. (2002). Eğitimde dönüşüm eğitimde yeni değerler. Ankara: Pegem Yayınc1lık.

Rokeach, M. (1973). The nature of human values. New York: Free Press.

Schwartz, S. H. (1994). Beyond individualism and collectivism: New cultural dimensions of values. U. Kim, H. C. Triandis, Ç. Kağıtçıbaşı, S. Choi, and G. Yoon (Eds.), Individualism and collectivism: Theory, method, and applications, içinde (s. 85-119). Thousand Oaks, CA: Sage.

Selçuk, Z. (2005). Gelişim ve ögrenme. Ankara: Nobel Yay.

Soykan, Ö. N. (2007). Genel geçer bir ahlak olanaklı mıdır? Değerler ve Eğitimi Uluslararası Sетроzуити, DEM Yayınları, s. 45-54.

Şen, Ü. (2008). Altıncı sınıf Türkçe ders kitaplarındaki metinlerin ilettiği değerler açısından incelenmesi. Uluslararası Sosyal Araştırmalar Dergisi, 1(5), 763-779.

Thapor, M. (2001). What is values education? www.valueseducation.edu.au/verve /_resources/ values_education_programme_01213_online_FINAL.pdf, (Erişim tarihi: 14 Aralık 2016).

Whitney, I. B. (1986). The status of values education in the middle and junior high schools of Tennesse. Ph.D Thesis, Tennesse State University, USA.

Yazar, T., Erkuş, S. (2013). Okul öncesi öğretmenlerinin okul öncesi eğitim programındaki değerler eğitimine ilişkin görüşlerinin değerlendirilmesi. Dicle Üniversitesi Ziya Gökalp Eğitim Fakültesi Dergisi, 20, 196-211.

Yıldırım, A., Şimşek, H. (2013). Sosyal bilimlerde nitel araştırma yöntemleri. Ankara: Seçkin Yayıncilik.

Yücel, C. (2014). Eğitim bilimine giriş (Ed. Cevat Celep). (4. Bask1). Ankara: Anı Yayıncılık.

Ziebertz, H. G. (2007). Çok kültürlü bir toplumda değerler eğitimi modelleri. Değerler ve Eğitimi Uluslararası Sempozyumu, DEM Yayınları, s. 445-466. 